\title{
Profile of tuberculosis patients in Natal-RN, Brazil, from 2010 to 2018: a documentary study
}

\author{
Perfil de acometidos por tuberculose em Natal-RN, Brasil, entre os anos de 2010 a 2018: um \\ estudo documental
}

\author{
F. P. Andrade Júnior ${ }^{*}$; T. W. B. Alves 2 ; I. H. M. Aciole²; B. K. S. Farias ${ }^{3}$; L. V. \\ Cordeiro ${ }^{1}$; E. O. Lima ${ }^{1}$ \\ ${ }^{1}$ Programa de Pós-Graduação em Produtos Naturais e Sintéticos Bioativos, Universidade Federal da Paraíba, 58033- \\ 455, João Pessoa-PB, Brasil. \\ ${ }^{2}$ Universidade Federal de Campina Grande, 58175-000,Cuité-PB, Brasil \\ ${ }^{3}$ Faculdade de Enfermagem e de Medicina Nova Esperança, 58067-695, João Pessoa-PB, Brasil.
}

*juniorfarmacia.ufcg@outlook.com

(Recebido em 26 de julho de 2019; aceito em 28 de outurbo de 2019)

\begin{abstract}
The present study aimed to elucidate the epidemiological profile of tuberculosis patients in Natal-RN between the years 2010 and 2018. This was an epidemiological, retrospective and documentary study, in which the recovery of the secondary data occurred from the "Departamento de Informática do Sistema Único de Saúde (DATASUS)" in Brazil. The following variables were studied: year of notification, gender, age, schooling, area of residence, ethnicity and factors that facilitate the onset of tuberculosis. Statistical association was performed using the Chi-Square test. In the year 2011, the highest percentage of notifications for tuberculosis was received (12.4\%) in Natal-RN. The profile of the affected individuals was predominantly male $(69.5 \%)$, between 20 and 39 years of age (43.8\%), low educational levels (41.3\%), mulattoes (68.2\%) and urban residents $(94.1 \%)$. When gender was associated with factors that facilitate the onset of tuberculosis, it was observed that males presented higher percentages of positivity for Human Immunodeficiency Virus (HIV) (16.3\%), Acquired immunodeficiency syndrome (AIDS) (15.8\%), alcoholism (34\%) and smoking (13.5\%), while in females the highest rates of this correlation were with Diabetes mellitus (10.4\%). In addition, a statistically significant association was found between gender with tobacco and alcohol consumption $(<0.001)$ and with the presence of diabetes and Aids $(<0.001)$. The data found in this study may serve as an auxiliary for developing more specific public policies for those most susceptible to tuberculosis in Natal-RN. Key words: Tuberculosis, Mycobacterium, Epidemiology.
\end{abstract}

O presente trabalho teve como objetivo elucidar o perfil epidemiológico de acometidos por tuberculose em Natal-RN, entre os anos de 2010 a 2018. Tratou-se de um estudo epidemiológico, retrospectivo e documental, em que a recuperação dos dados secundários se deu a partir do Departamento de Informática do Sistema Único de Saúde do Brasil. Foram estudadas as variáveis: ano de notificação, gênero, faixa etária, escolaridade, zona de residência, etnia e fatores facilitadores para o surgimento da tuberculose. A associação estatística foi realizada por meio do teste Qui-Quadrado. O ano de 2011 foi aquele em evidenciou-se o maior percentual de notificações $(12,4 \%)$ para tuberculose em Natal-RN. O perfil de acometidos foi de indivíduos majoritariamente do gênero masculino $(69,5 \%)$, entre 20 a 39 anos de idade $(43,8 \%)$, baixa escolaridade $(41,3 \%)$, pardos $(68,2 \%)$ e residentes da zona urbana $(94,1 \%)$. Ao associar o gênero com fatores que facilitam o desenvolvimento da tuberculose, observou-se que os homens apresentaram maiores porcentagens de positividade para o Vírus da Imunodeficiência Humana (VIH) (16,3\%), Síndrome da Imunodeficiência Adquirida (SIDA) $(15,8 \%)$, alcoolismo (34\%) e tabagismo (13,5\%), enquanto que no gênero feminino as maiores taxas dessa correlação foram com Diabetes mellitus $(10,4 \%)$. Além disso, observou-se associação estatisticamente significativa entre o gênero e o consumo de tabaco e álcool $(<0,001)$ e da presença de diabetes e SIDA $(<0,001)$. Assim, os dados disponibilizados nesta pesquisa podem servir como subsídio para o desenvolvimento de políticas públicas mais específicas para os segmentos mais suscetíveis a tuberculose em Natal-RN.

Palavras-chave: Tuberculose, Mycobacterium, Epidemiologia. 


\section{INTRODUCTION}

Tuberculosis is an infectious-contagious disease. Its etiological agent (Mycobacterium tuberculosis) was discovered in 1882 by the researcher Robert Koch. The bacterium is characterized morphologically as an immobile, non-encapsulated bacillus [1,2]. M. tuberculosis can be passed from individual to individual by droplets of saliva, and especially through sneezing and/or coughing. Upon reaching the lower respiratory system it may foment tuberculosis if the affected person presents impaired immunity [3].

Tuberculosis mainly affects the lungs; however, the bacillus may spread throughout the bloodstream in its extra-pulmonary form. In Brazil, the disease affects around 70 thousand people causing approximately 4,500 deaths per year [4]. Individuals afflicted by the disease may present fever, fatigue, weight loss, sweating, and continuous dry cough for more than three weeks. Since the recent description of Acquired Immunodeficiency Syndrome (AIDS), tuberculosis has become increasingly common $[4,5]$.

Despite the many campaigns and preventive measures promoted in Brazil, tuberculosis is still considered an important public health problem [4, 6]. Yet, even considering the acknowledged relevance of the issue, one observes that there is a significant scarcity in the literature of studies that allow tracing the profiles of patients affected by the disease, especially in Northeastern cities and states, such as Natal-RN. Thus, the present study aimed to elucidate the epidemiological profile of tuberculosis patients in Natal-RN between the years 2010 and 2018.

\section{MATERIAL AND METHODS}

\subsection{Study design}

This was an epidemiological, retrospective, and documentary study in which secondary data recovery occurred from access to the Brazilian "Departamento de Informática do Sistema Único de Saúde (DATASUS)".

\subsection{Study locale}

The city of Natal is the capital of Rio Grande do Norte state, located in Brazilian Northeast. In the year 2018 the city had an estimated population of 877,640 inhabitants. Its per capita income approaches three minimum monthly salaries and in 2009 Natal maintained about 149 health facilities linked to the "Sistema Único de Saúde" [7].

\subsection{Analyzed variables}

The following variables were studied: notification (year), gender, age, schooling, residence zone, ethnicity, facilitating factors for developing tuberculosis, and associations between "gender and age" and "gender and facilitating factors". From these variables, relative and absolute frequencies were analyzed.

\subsection{Statistical analysis}

Statistical analysis was performed using version 13.0 of the Statistical Package for the Social Sciences (SPSS). The chi-square test was applied and the results were considered statistically significant for rejecting null hypotheses when $\mathrm{p}<0.05$.

\section{RESULTS AND DISCUSSION}

Between 2010 and 2018, 5,676 cases of tuberculosis were detected in Natal-RN (Figure 1). 


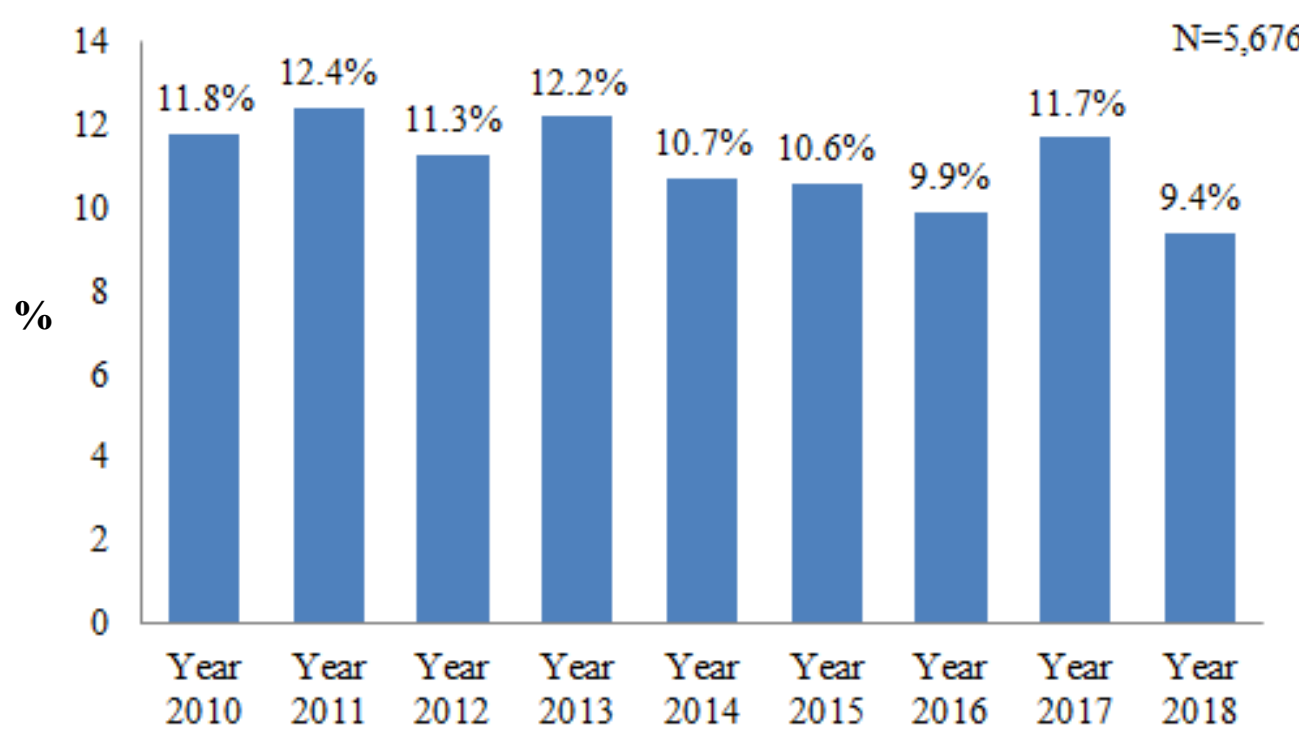

Figure 1: Percentage of confirmed cases of tuberculosis in Natal-RN, between the years 2010 to 2018.

In 2011, the highest number of cases was reported, 12.4\%, followed by the years 2013 and 2010 with $12.2 \%$ and $18.1 \%$ of the notifications. The implementation of rapid diagnostics from 2011 can help to justify the large number of cases reported in the same year in the city of Natal-RN. However, it is widely evidenced that the Brazilian Northeastern capitals, especially the coastal capitals, due to larger urban agglomerations, present greater difficulty in controlling and combating the disease, making it a major challenge to reduce the number of cases over the years [10].

In addition, between 2010 and 2013 there were slight variations in the numbers of infected individuals, with a slight decrease between 2014 and 2016, followed by an increase in those affected in 2017, and a sharp decrease in 2018. These results differ from a study carried out in Piauí where there were 4,847 cases of tuberculosis, between 2010 and 2014, observing a decrease in cases over each year, with 2014 being the lowest percentage year at 18.4\% [8]. In addition, the decrease in cases was observed throughout the Brazilian Northeast from the years 2009 to 2014. This is believed to be related to the effectiveness of focused educational measures taken with the population $[9,10]$. Until 2016 Natal-RN had a decreasing number of cases, which corroborates with the reduction in the incidence of tuberculosis in Brazil between 2008 and 2015 [10].

The decrease in cases by 2016 may be related to the implementation, in 2011, of Ordinance $\mathrm{n}^{\circ} 444$. This document aimed to increase the support of research related to tuberculosis, as well as guarantees of prevention and fight against the disease, especially with regard to refers to the development of actions/strategies in poor communities, black population, prisoners, homeless people, indigenous communities and people living with HIV/AIDS, which may have directly reflected in the decrease of cases in subsequent years in several Brazilian capitals, including in Natal-RN [11].

In 2018 was the year in which the smallest number of cases was reported in Natal-RN, which can be explained by the implementation of the "Plano Nacional pelo Fim da Tuberculose". This plan has goals to reduce the disease rate by the year 2035 through the implementation, begun in 2017, of greater prevention and care through accurate diagnosis, appropriate pharmacological treatment, intensification of collaborative tuberculosis-HIV activities and preventive actions. In addition, there is the objective of implementing policies that allow the promotion of prevention and care actions, strengthening of intra and intersectoral articulations and the participation of civil society. It is also intended to improve the quality of information systems in which tuberculosis cases are recorded, to know the real epidemiological situation of the disease in the country and, finally, this plan still seeks to intensify research and innovations that allow greater control of the disease $[12,13]$, contributing to a higher level of health education, early diagnosis, and adequate antibiotic therapy. In Figure 2, the percentage of tuberculosis patients can be observed, taking gender into account. 


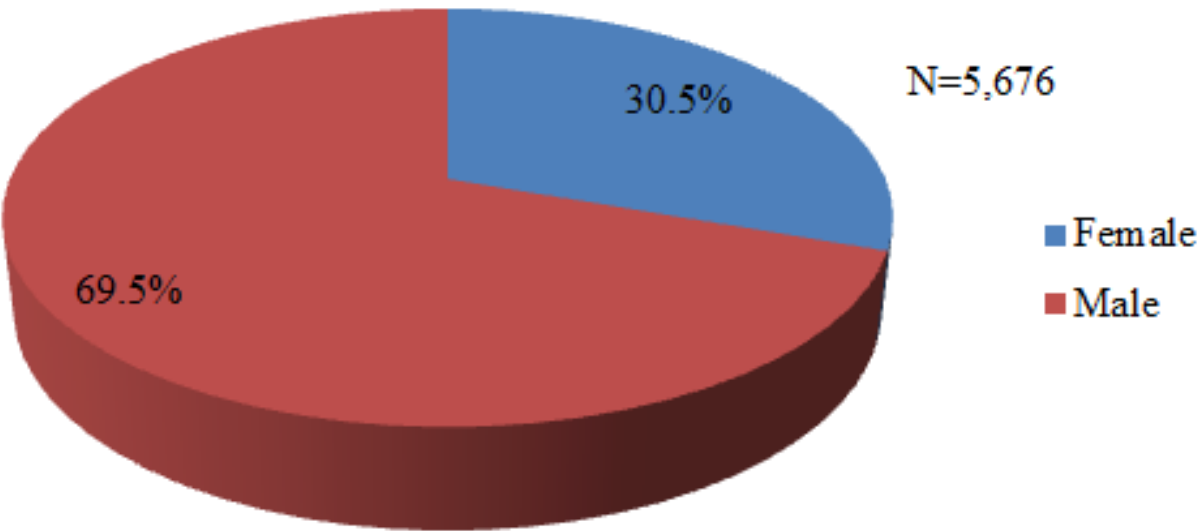

Figure 2: Percentage of tuberculosis patients, classified by gender, in Natal-RN, between the years 2010 and 2018 .

In Natal-RN, male subjects were those most often diagnosed with tuberculosis (69.5\%). These results are similar to a study carried out in Caxias-MA, where of 570 patients, between 2006 and 2017, 65.6\% were men [14], and in demonstrated agreement with a study developed by Souza Júnior et al. (2018) [15] in which, during the years from 2012 to 2016, in the state of Bahia, the number of male patients with tuberculosis, accounting for about $70 \%$, was twice as high as for females. In Montes Claros-MG, it was observed that of 661 patients with tuberculosis, $60.4 \%$ of the patients were male [16]. This predominance of males has been associated with cultural issues, due to alcohol and/or tobacco consumption, which may compromise immunity and nutritional status, and thus increase the likelihood of acquiring tuberculosis [17].

In Table 1 it is possible to observe the two associations between age group and gender of the affected individuals. By age group, the majority of patients were 20 to 39 years old (43.6\%) of both genders, $714(41.3 \%)$ female and 1,774 (44.9\%) male, followed by individuals between 40 and 59 years old (33.7\%). This finding partially corroborates a study conducted in Natal-RN between 2006 and 2010, which found that of 2,632 individuals, $22.7 \%$ were between 35 and 44 years old [18]. In the municipality of Rondonópolis-MT, of 134 tuberculosis patients, $47 \%$ were between 35 and 54 years old [19]. Moreover, it was observed that in Natal-RN, there is a low prevalence of individuals with tuberculosis for both genders up to 14 years of age, which may be related to the temporary immunity granted by BCG vaccine [20].

Table 1: Association between age group and gender of patients affected by tuberculosis in Natal-RN between the years 2010 and 2018.

\begin{tabular}{ccccccc}
\hline \multirow{2}{*}{ Age group } & \multicolumn{2}{c}{ Female } & \multicolumn{2}{c}{ Male } & \multicolumn{2}{c}{ Total } \\
\cline { 2 - 7 } & $\mathbf{N}$ & $\mathbf{\%}$ & $\mathbf{N}$ & $\mathbf{\%}$ & $\mathbf{N}$ & $\mathbf{\%}$ \\
\hline < 1 year old & 14 & 0.8 & 18 & 0.5 & 32 & 0.6 \\
1-4 years old & 26 & 1.5 & 22 & 0.6 & 48 & 0.8 \\
5-9 years old & 17 & 1.0 & 20 & 0.5 & 37 & 0.6 \\
10-14 years old & 37 & 2.1 & 36 & 0.9 & 73 & 1.3 \\
15-19 years old & 111 & 6.4 & 182 & 4.6 & 293 & 5.2 \\
20-39 years old & 714 & 41.3 & 1,774 & 44.9 & 2,488 & 43.8 \\
40-59 years old & 531 & 30.7 & 1,376 & 34.9 & 1,907 & 33.6 \\
$\geq$ 60 years old & 279 & 16.2 & 519 & 13.1 & 798 & 14.1 \\
\hline Total & 1,729 & 100 & 3,947 & 100 & 5,676 & 100 \\
\hline
\end{tabular}

The educational level of tuberculosis patients can be observed below (Table 2). About $41.4 \%$ of individuals affected by tuberculosis in Natal-RN, between 2010 and 2018, had low education. These data endorse the results found by a study conducted in the state of Maranhão, between 2012 and 2016, which found that out of 9,492 patients, $68.5 \%$ had low education [21]. Additionally, in 
the municipality of Açailândia-MA, it was evidenced that of the 58 individuals affected in 2018, $84 \%$ of them had low levels of education [22].

Table 2. Level of schooling of those contracting tuberculosis in Natal-RN, between the years 2010 to 2018.

\begin{tabular}{ccc}
\hline Schooling & $\mathbf{N}$ & $\mathbf{\%}$ \\
\hline High schooling $* * * *$ & 285 & 5.0 \\
Average schooling *** & 941 & 16.6 \\
Low education level** & 2,346 & 41.3 \\
No schooling * & 420 & 7.4 \\
Ignored & 1,588 & 28 \\
Not applicable & 96 & 1.7 \\
\hline Total & 5,676 & 100 \\
\hline *Illiterate; ** incomplete or complete primary education; *** incomplete or complete secondary &
\end{tabular}

The predominance of low levels of education for individuals with tuberculosis in Natal-RN is relevant, because in illiterate individuals or with few years of schooling, there is evidence of greater abandonment of antituberculosis treatments and less access to information and services [23]. This can lead to phenomena of resistance, greater spread of the bacillus and even death. Moreover, it is important to highlight that a significant part of the people had their level of education ignored (28\%), indicating fragility at the time of data collection, while in smaller quantity $(1.7 \%)$ it was observed the inapplicability of schooling, since some of those affected, due to their young age, did not have enough time to study in any of the categories.

Regarding the place/area of residence, there was a predominance of individuals living in urban areas $(94.1 \%)$, followed by rural areas $(3.0 \%)$, unregistered areas $(2.1 \%)$ and peripheral areas. urban $(0.8 \%)$ These results are similar to those found in Belém-PA, where among 99 individuals affected by the disease, $97.1 \%$ lived in the urban area [24]. In addition, the prevalence of the disease in urban areas was also evident between 2007 and 2010 in the city of João Pessoa-PB, where of the 1,890 reported cases, $98.3 \%$ were individuals living in the urban area [25]. The occurrence of tuberculosis in large urban centers is mainly due to agglomeration, which facilitates exchange of pathogens in the air $[26,27]$. Table 3 presents the ethnicity of the tuberculosis patients.

Table 3: Ethnicity of tuberculosis sufferers in Natal-RN between the years 2010 to 2018.

\begin{tabular}{ccc}
\hline Ethnicity & $\mathbf{N}$ & $\boldsymbol{\%}$ \\
\hline White & 1,136 & 20.0 \\
Black & 376 & 6.6 \\
Yellow & 36 & 0.6 \\
Mulatto & 3,870 & 68.2 \\
Indigenous & 09 & 0.2 \\
Ignored & 249 & 4.4 \\
\hline Total & 5,676 & 100 \\
\hline
\end{tabular}

It was found that the mulatto population was the most affected by tuberculosis, accounting for $68.2 \%$ of the total infected individuals, which may be justified by the fact that most of the Natal population is predominantly mulatto [7]. The second highest rate was in white individuals (20\%). An even higher prevalence of infection in mulatto individuals was that observed in Açailândia-MA, in 2018, where among 56 infected with tuberculosis, $89 \%$ were mulatto [22].

The predominance of infected mulatto individuals is of concern, as it raises an issue that has been highlighted in public health, where racism and stigmatization related to ethnicity make these individuals even avoid going to health services, presenting greater difficulty in continuing 
pharmacological treatment, with a likelihood of complete discontinuation of therapy when compared to infected white individuals $[8,28,29]$.

In order to trace the profile of individuals affected by any disease, it is important to observe not only socio-demographics, but also cultural issues and even pathological conditions that may facilitate the emergence of comorbidities or diseases such as tuberculosis. In the table below it is possible to observe the facilitating factors for the onset of tuberculosis and the association among genders.

Table 4: Association between gender and factors that facilitate tuberculosis emergence in infected individuals in the city of Natal-RN between the years 2010 to 2018.

\begin{tabular}{|c|c|c|c|c|c|c|c|}
\hline \multirow[t]{2}{*}{ Group } & \multicolumn{2}{|c|}{ Female } & \multicolumn{2}{|c|}{ Male } & \multicolumn{2}{|c|}{ Total } & \multirow[t]{2}{*}{$\boldsymbol{P}$} \\
\hline & $\mathbf{N}$ & $\%$ & $\mathbf{N}$ & $\%$ & $\mathbf{N}$ & $\%$ & \\
\hline \multicolumn{8}{|c|}{ HIV test result } \\
\hline Positive & 14 & 0.8 & 18 & 0.5 & 32 & 0.6 & \\
\hline Negative & 26 & 1.5 & 22 & 0.6 & 48 & 0.8 & \\
\hline Unrealized & 17 & 1.0 & 20 & 0.5 & 37 & 0.6 & $*$ \\
\hline In progress & 37 & 2.1 & 36 & 0.9 & 73 & 1.3 & \\
\hline Ignored & 111 & 6.4 & 182 & 4.6 & 293 & 5.2 & \\
\hline Total & 1,729 & 100 & 3,947 & 100 & 5,676 & 100 & \\
\hline \multicolumn{8}{|c|}{ State of AIDS } \\
\hline Yes & 195 & 11.3 & 622 & 15.8 & 817 & 14.4 & \\
\hline No & 951 & 55.0 & 2,093 & 53 & 3,044 & 53.6 & $<0.001$ \\
\hline Ignored & 583 & 33.7 & 1,232 & 31.2 & 1,815 & 32.0 & \\
\hline Total & 1,729 & 100 & 3,947 & 100 & 5,676 & 100 & \\
\hline \multicolumn{8}{|l|}{ Smoking } \\
\hline Yes & 120 & 7.0 & 531 & 13.5 & 651 & 11.5 & \\
\hline No & 499 & 28.8 & 924 & 23.4 & 1,423 & 25.1 & $<0.001$ \\
\hline Ignored & 1,110 & 64.2 & 2,492 & 63.1 & 3,602 & 63.4 & \\
\hline Total & 1,729 & 100 & 3,947 & 100 & 5,676 & 100 & \\
\hline \multicolumn{8}{|l|}{ Alcoholism } \\
\hline Yes & 175 & 10.1 & 1,342 & 34.0 & 1,517 & 26.7 & \\
\hline No & 1,118 & 64.7 & 1,652 & 41.9 & 2,770 & 48.8 & $<0.001$ \\
\hline Ignored & 436 & 25.2 & 953 & 24.1 & 1,389 & 24.5 & \\
\hline Total & 1,729 & 100 & 3,947 & 100 & 5,676 & 100 & \\
\hline \multicolumn{8}{|l|}{ Diabetes } \\
\hline Yes & 189 & 10.9 & 321 & 8.1 & 510 & 9.0 & \\
\hline No & 1,116 & 64.6 & 2,478 & 62.8 & 3,594 & 63.3 & $<0.001$ \\
\hline Ignored & 424 & 24.5 & 1,148 & 29.1 & 1,572 & 27.7 & \\
\hline Total & 1,729 & 100 & 3,947 & 100 & 5,676 & 100 & \\
\hline
\end{tabular}

There was a statistically significant association between the gender of tuberculosis individuals and alcoholism, smoking, diabetes and AIDS status $(\mathrm{p}<0.001)$.

Approximately $16.3 \%$ of men and $11.9 \%$ of women affected by tuberculosis were HIV positive. In addition, $15.8 \%$ of men and $11.3 \%$ of women had AIDS. This finding is relevant because it is 
evident that patients with HIV / AIDS are more likely to develop resistance to tuberculosis and have a greater chance of reactivating latent infection. These individuals also have greater side effects from drug therapy, tuberculostatic malabsorption, malnutrition, and delays in bacilloscopic diagnosis $[30,31]$.

Regarding smoking, it was evidenced mainly in infected males (13.5\%). Tobacco use has been associated with a greater likelihood of latent tuberculosis infection progressing to the active form, as well as being associated with greater difficulties in adherence to treatment, resistance phenomena and relapse cases [32]. It is believed that smoking may contribute to the development of tuberculosis for two main reasons: first, due to nicotine's ability to act on $\alpha 7$-nicotinic receptors, thus decreasing macrophage tumor necrosis factor (TNF- $\alpha$ ) production, hindering the recruitment of neutrophils, monocytes and decreasing the production of other cytokines that contribute to greater microbicidal activity in both dendritic cells and macrophages. The second reason is due to the ability of cigarettes to negatively regulate the production of important cytokines, such as interleukin-2 (IL-2) and TNF- $\alpha$, preventing the formation of granulomas [33, 34].

Alcoholism was the factor that facilitates the onset of tuberculosis in which the largest number of individuals was observed, accounting for $26.7 \%$ of those affected by tuberculosis, with mainly male individuals as alcoholics (34\%). Alcohol use by tuberculosis individuals has been associated with high therapy discontinuation, occurring mainly due to the development of hepatotoxicity [33].

Diabetes mellitus (DM) was the only one that displayed a higher percentage of women affected $(10.9 \%)$ than men $(8.1 \%)$. It is believed that DM can lead to an increase in the probability of developing tuberculosis by up to three times more than those who do not have this metabolic disease. This can be explained especially in cases where there is hyperglycemia and hyperinsulinemia, in which the patient presents compromised macrophage and neutrophil activity [33].

However, it is necessary to emphasize that the correlation with the facilitating factors for tuberculosis was predominantly related to males compared to females. This finding is mainly associated with higher consumption of alcohol and tobacco by men, as well as greater difficulty in maintaining self-care and the search for health services [33, 34, 35].

It is important to emphasize that a description of social, and economic demographics for a given population is not always sufficient to truly understand its profile, which in turn makes it difficult to develop specific public policies that can predict the segments which will present the most susceptible individuals. In addition, due to this research makes use of secondary data, the information described in this article does not represent reality in its entirety. However, this fact does not diminish the importance of the exposed data, as these may serve as a basis for the development of other health research or indicators and even public policies that mainly cover the profile of individuals more susceptible to the disease in Natal-RN.

\section{CONCLUSION}

Between 2010 and 2018, 2011 was the year in which the highest percentage of tuberculosis notifications in Natal-RN was evidenced. The profile of affected individuals was predominantly male, 20 to 39 years old, with low education level, mulattos and urban residents. When gender was associated with factors that facilitate the onset of tuberculosis, it was observed that males presented higher percentages of positivity for HIV, AIDS, alcoholism and smoking, while in females the highest rates of this correlation were with diabetes mellitus. The data available in this research may serve as an aid in the development of public policies that cover social, demographic, cultural and pathological issues for the population most susceptible to tuberculosis in Natal-RN. In addition, they can serve as a basis for new researches that shares the same central focus.

\section{REFERENCES}

1. Kozakevich GV, Silva RM. Tuberculose: revisão de literatura. Arq Caterin Med. 2015;44(4):34-47.

2. Brasil. Ministério da Saúde. Tuberculose na Atenção Primária a Saúde. 2ed. Brasília: Ministério da Saúde; 2011. 
3. Secretaria Estadual de Saúde do Paraná (SES-PR). Tuberculose [acesso em 17 dez 2018]. Disponível em: http://www.saude.pr.gov.br/modules/conteudo/conteudo.php?conteudo=93.

4. Brasil. Ministério da Saúde. Tuberculose [acesso em 16 dez 2018]. Disponível em: http://portalms.saude.gov.br/saude-de-a-z/tuberculose

5. Souza RC. Universidade Aberta do SUS. Tuberculose [acesso em 17 dez 2018]. Disponível em: https://ares.unasus.gov.br/acervo/handle/ARES/2244.

6. Rodrigues VC, Moreira LC, Lima RS, Lourenço SQC, Resende RFB. Tuberculose no século XXI: Revisão de literatura com relato de caso em cavidade oral. Int J Sci Dent. 2018;49(1):1-20. doi:10.22409/ijosd.v1i49.394

7. Instituto Brasileiro de Geografia e Estatística (IBGE). Natal [acesso em 17 dez 2018]. Disponível em: https://cidades.ibge.gov.br/brasil/rn/natal/panorama.

8. Silva NG, Barros S, Azevedo FC, Batista LE, Policarpo VC. O quesito raça/cor nos estudos de caracterização de usuários de Centro de Atenção Psicossocial. Saúde Soc. 2017;26(1):100-114. doi:10.1590/s0104-12902017164968

9. Grosch CA, Nascimento EL, Nascimento KS, Diniz RM, Pacheco WB, Sauaia BA. Prevalência da tuberculose no Maranhão. Rev Investig Bioméd. 2015;7(1):28-34. doi:10.24863/rib.v7i1.17

10. Cozer AM, Assis LPF, Graciano AR, Amâncio VC, Dias DCS. Panorama epidemiológico da tuberculose no Brasil. Rev Educ Saúde. 2016;4(2):43-50.

11. Brasil. Ministério da Saúde. Resolução no 444, de 6 de julho de 2011 [acesso em 29 set 2019]. Disponível em: http://bvsms.saude.gov.br/bvs/saudelegis/cns/2011/res0444_06_07_2011.html

12. Pereira VLT, Pereira IT, Elias PG, Medeiros PCM, Souza. A incidência de tuberculose no Vale do Ribeira. Rev Gestão Foco. 2017;9(1):90-102.

13. Brasil. Ministério da Saúde. Secretaria de Vigilância em Saúde. Departamento de Vigilância das Doenças Transmissíveis. Brasil Livre da Tuberculose: Plano Nacional pelo Fim da Tuberculose como Problema de Saúde Pública. Brasília, DF: Ministério da Saúde; 2017.

14. Macedo JL, Oliveira ASSS, Pereira IC, Assunção MJSM. Perfil epidemiológico da tuberculose em um Município do Maranhão. ReonFacema. 2017;3(4):699-705.

15. Souza Júnior EV, Nunes GA, Cruz DP, Boery EN, Boery RNSO. Internamientos hospitalarios e impacto financiero por Tuberculosis Pulmonar en Bahia, Brasil. Enferm Actual Costa Rica. 2018; 35: 38-51. doi:10.15517/REVENF.V0I35.31868

16. Jesus BFG, Souza PGO, Silveira MF, Santo LRE. Perfil epidemiológico da tuberculose na cidade de Montes Claros de 2005 a 2009. Rev Bras Farm. 2012;93(1):80-84.

17. Silva DR, Muñoz-Torrico M, Duarte R, Galvão T, Bonini EH, Arbex FF, et al. Fatores de risco para tuberculose: diabetes, tabagismo, álcool e uso de outras drogas. J Bras Pneumol. 2018;44(2):145-52. doi:10.1590/s1806-37562017000000443

18. Cavalcante EFO, Silva DMGV. Perfil de pessoas acometidas por tuberculose. Rev Rene. 2013;14(4):7209.

19. Moraes MG, Gardenghi G. Perfil epidemiológico de indivíduos com tuberculose pulmonar no município de Rondonópolis - MT. RESC. 2015;5(2):1-18.

20. Pereira SM, Dantas OMS, Ximenes R, Barreto ML. Vacina BCG contra tuberculose: efeito protetor e políticas de vacinação. Rev Saúde Pública. 2017;41(supl. 1):59-66. doi:10.1590/S003489102007000800009

21. Oliveira MSR, Sousa LC, Baldoino LS, Alvarenga AA, Silva MNP, Elias SCG, et al. Perfil epidemiológico dos casos de tuberculose no estado do Maranhão nos anos de 2012 a 2016. Rev Pre Infec Saúde. 2018;4:1-8. doi:10.26694/repis.v4i0.6896

22. Moraes MFV, Corrêa RGCF, Coutinho NPS, Caldas AJM, Silva TC, Santos KCB, et al. Perfil epidemiológico de casos de tuberculose em um minicípio prioritário no estado do Maranhão. Rev Pesq Saúde. 2017;18(3):147-150.

23. Furlan MCR, Oliveira SP, Marcon SS. Fatores associados ao abandono do tratamento de tuberculose no estado do Parana. Acta Paul Enferm. 2012;25(1):108-114. doi:10.1590/S0103-21002012000800017

24. Freitas VMTM, Santos CC, Silva MM, Rocha GA. Perfil clínico-epidemiológico de pacientes portadores de tuberculose atendidos em uma unidade municipal de saúde de Belém, Estado do Pará, Brasil. Rev PanAmaz Saúde. 2016;7(2):45-50. doi:10.5123/S2176-62232016000200005

25. Coutinho LASA, Oliveira DS, Souza GF, Fernandes Filho GNC, Saraiva MG. Perfil epidemiológico da tuberculose no município de João Pessoa-PB, entre 2007- 2010. Rev Bras Ci Saúde. 2012;16(1):35-42. doi:10.4034/RBCS.2012.16.01.06

26. Silva PVC, Ghiraldi LD. Tratamento farmacológico da tuberculose e seus efeitos adversos. Uningá Rev. 2010;4(1):65-74.

27. Cardoso LC, Melquiades R, Magalhães JA, Carvalho SS, Rosa G, Merlini LS, et al. Aspectos epidemiológicos dos pacientes notificados com tuberculose na microrregião de Umuarama-Noroeste 
Paranaense de 2009 a 2014. Arq. Ciênc. Saúde UNIPAR. 2018;22(3):157-163. doi:10.25110/arqsaude.v22i3.2018.6162

28. Pôrto A. Representações sociais da tuberculose: estigma e preconceito. Rev Saúde Pública. 2007;41(Supl. 1):43-49. doi:10.1590/S0034-89102007000800007.

29. Souza SS, Silva DMGV, Meirelles BHS. Representações sociais da tuberculose. Acta Paul Enferm. 2010;23(1):23-28. doi:10.1590/S0103-21002010000100004

30. Singh S, Munawwar A. Aids associeted tuberculosis:a catastrophic collision to evade the host immune system. Tuberculosis. 2012;92(5):384-387. doi:10.1016 / j.tube.2012.05.006

31. Ferreira DP, Souza FA, Motta MCS. Prevalência da coinfecção HIV/TB em pacientes de um hospital de referência na cidade do Rio de Janeiro. Rev Pesq Cuidado Fundam. (Online). 2019;11(2):358-362. doi:10.9789/2175-5361.2019.v11i2.358-362

32. Novotny T, Hendrickson E, Soares ECC, Sereno AB, Kiene SM. HIV/AIDS, tuberculose e tabagismo no Brasil: uma sindemia que exige intervenções integradas. Cad Saúde Pública. 2017;33(Supl. 3):1-4. doi:10.1590/0102-311x00124215

33. Silva DR, Muñoz-Torrico M, Duarte R, Galvão T, Bonini EH, Arbex FF, et al. Fatores de risco para tuberculose: diabetes, tabagismo, álcool e uso de outras drogas. J Bras Pneumol. 2018;44(2):145-152. doi:10.1590/s1806-37562017000000443

34. Rabahi MF. Tuberculose e tabagismo. Pulmão RJ. 2012;21(1):46-49.

35.Zagmignan A, Alves MS, Sousa EM, Lima Neto LG, Sabbadini PS, Monteiro SG. Caracterização epidemiológica da tuberculose pulmonar no Estado do Maranhão, entre o período de 2008 a 2014. Rev Investig Bioméd. 2014;6(1):6-13. 